\title{
Organizational Environment and Nurses' Job Satisfaction: A Study on Private Hospital in Bangladesh
}

\author{
Md. Azmol Hossain ${ }^{1}$, Mohitul Ameen Ahmed Mustafi ${ }^{2 *}$, Md. Mohedul Islam ${ }^{3}$, Md. Rafiqul Islam ${ }^{4}$ \\ ${ }^{1,2,3}$ Senior Lecturer, Department of Business Administration, School of Business, Uttara University (UU), Dhaka, BANGLADESH \\ ${ }^{4}$ Lecturer, Department of Business Administration, School of Business, Uttara University (UU), Dhaka, BANGLADESH \\ *E-mail for correspondence: mustafi559@gmail.com
}

Received: Nov 23, 2016;

Accepted: Dec 30, 2016;

Published: Feb 8, 2017

Source of Support: Nil

No Conflict of Interest: Declared

\begin{abstract}
This correlation based descriptive study is designed to describe and examine the relationship between organizational environment and nurses' job satisfaction within the private health care context in Bangladesh. The study is based on different private medical college and hospital in Bangladesh. Respondents are selected using a convenient sampling procedure of 139 nurses working at these hospitals and involved in caring patients directly. Therefore, 139 responded questionnaires are used for analysis. Data has been collected through face to face interview in 2015. Inferential Statistics like as Exploratory Factor Analysis and Confirmatory Factor Analysis are used to test the relationship between organizational environment and nurses' job satisfaction. The reliability of Organizational Environment and Nurses' Job Satisfaction are 0.75 . Descriptive statistics has been used to explain the demographic data of the respondent of those private hospitals. Factor analysis reveals that only four influential factors like, Organizational Structure, Organizational Responsibility, Reward\& Recognition, and Organizational Standard of the organizational environment have a significant influence on nurses' job satisfaction. On the contrary, four influential factors of nurse job satisfaction like Payment of Nurse, Interaction of Nurse, Task Requirement and Organizational Policy have an influence on the organizational environment. Confirmatory factor analysis explains that only three influential factors like, Organizational Structure, Organizational Responsibility, and Organizational Standard have influence on nurse job satisfaction and the organizational environment has been influenced by three influential factors like Payment of Nurse, Interaction of Nurse, and Organizational Policy. The findings of this study suggest that organizational environment should be employee friendly, policies should be inspiring for nurse; nurses should be allowed to make their decision and organization should ensure proper evaluation and promotion of the nurses that eventually will maximize better services.
\end{abstract}

Keywords: Nurses' Job Satisfaction, Organizational Environment, Private Hospital, Bangladesh

\section{INTRODUCTION}

Nursing is a recognized noble profession that has relations with the healing ability and a sense of reflection to serve humanity. Variations in health care sectors including reorganization, redesigning, intensifying the roles of health care professionals are the cause of nurses to extend their responsibilities. They have to face many difficulties in providing care to the patients with their rapid changing roles and diverging environment (Mok \& Au-Yeung, 2002). Nurses need enthusiasm and feeling love, caring attitude and alarming concern to fulfill the needs of their patients (Henry \& Henry, 2004). Moreover, worldwide nursing is dealing with the shortage of work force that creates a significant threat which is society's most vulnerable populations and has adverse implications for the quality of health care (Buchan \& Aiken, 2008). Dealing with these situations, nurses' job satisfaction has become a major concern in the health care sector globally (Bradley \& Cartwright, 2004). Job satisfaction among nurses is a major concern in Bangladesh; no research evidence has existed about the factors associated with nurses' job satisfaction in the country. In this regards, some surveys reported that job satisfaction among nurses in Bangladesh was near to the ground (Hossain, 2008; WHO, 2003). According to WHO (2003), in Bangladesh, $90 \%$ of the nurses were not satisfied with their job. Among the nurses in one public hospital and one private hospital which found that $63 \%$ of nurses were dissatisfied with their job (Hossain, 2008). Finally, based on the review of above-related literature, it was 
expected that existing working environment may be a major concern in Bangladesh health care industry that would contribute to nurses' job satisfaction (Hossain, 2008; Nursing Taskforce, 1994; Zaman, 2004). The researchers value that if nurses are not satisfied with their job, this will negatively effect on the entire health care services of the country in the future. People will be less willing to serve in the nursing profession thus a shortage of nurses will be a long-standing problem for Bangladesh. Also, it may affect the quality of patient concern, and thus, the public acceptances were decreased towards the current standard of health care in the hospitals. Therefore, it is imperative to investigate the factors contributing to nurses' job satisfaction in the context of the health care organization in Bangladesh. With this regard, the present study was designed to explore the relationship between organizational environment and nurses' job satisfaction.

\section{LITERATURE REVIEW}

Job satisfaction is one's feeling or state-of-mind regarding the nature of work. It is one of the most frequently measured organizational variables in both researches and in the organizational settings.

French (1994) viewed job satisfaction as a person's emotional response to aspects of work or to the work itself. According to Robbins (1996), job satisfaction refers to an individual's general attitude towards his or her job. Spector (1997) said that job satisfaction is the scope of the people's like or dislike with their job. This definition suggests that job satisfaction is affected to reaction generally or globally affective that individuals hold about their job. According to Buss (1998), job satisfaction is an employee's perception that his or her job allows the fulfillment of important values and needs. The widely acceptable definition given by Locke (as cited in Elizabeth \&Adames, 2001) is that job satisfaction is "from the appraisal of one's job or job experiences state a pleasurable or positive emotional result". Cranny, Smith, and Stone (as cited in Brown \& Lent, 2004) defined job satisfaction as "an affective reaction to a job that is desired". The researchers have not proved the underlying difference between hygiene and motivating factors. In the poorer and developing countries sometimes in the developed counties as well as Nigeria, Nepal, Pakistan and Bangladesh, the hygiene factors mainly motivate people as most of the motivators are still absent themselves in workplaces. Nurses Job satisfaction is a major concern in Bangladesh. Thus, it was necessary to investigate the factors contributing to nurse job satisfaction. Moreover, in Bangladesh, no research evidence was existed or found about the factors contributing to nurses' job satisfaction. In this regards, most of the identified factors are important. For present study context, organizational environment was considered as the most vital contributing factors for job satisfaction of nurses. In this study, Stringer's (2002) conceptualized six organizational environment dimensions in the health care context have been selected to measure the nurses' working atmosphere. Stamps (1997) identified six components of nurse and health care professionals work satisfactions are also considered to measure the nurses' job satisfaction. Finally based on previous findings regarding the organizational environment and the nurse job satisfaction, the researchers assumed that these two concepts would be interrelated. The objective of this study was to explore and identify the relationship and factors between organizational environment and nurses' job satisfaction within the health care context of Bangladesh.

\section{Job satisfaction}

The nature of job satisfaction is attempted to understand the causes and its effects on work performance that is a complex process and considered as multidimensional and enduring constructs (Mullins, 2002; Stamps, 1997). According to Mullins, job satisfaction is a complex and multifaceted concept, which can represent different things to different people. Job satisfaction has a link with the motivation and it affects the human behavior in the organization (Robbins, 1996).Hall (as cited in Pietersen, 2005) stated that there is a lack of consensus as to what job satisfaction is and how the job satisfaction of employees is to be assessed. Bradley and Brain (2003) explained that job satisfaction represents the attitude of an individual about work and is influenced by individual's motivation to the work.

\section{Definition of Job Satisfaction}

Job satisfaction is one's feelings or state-of-mind regarding the nature of work. It is one of the most frequently measured organizational variables in both researches and in the organizational settings. French (1994) viewed job satisfaction as a person's emotional response to aspects of work or to the work itself. According to Robbins (1996), job satisfaction refers to an individual's general attitude towards his or her job. Spector (1997) defined it as "the extent to which people like or dislike their job". This definition suggests that job satisfaction is general or global affective reaction that individuals hold about their job. According to Buss (1998), job satisfaction is an employee's perception that his or her job allows the fulfillment of important values and needs.

The widely acceptable definition given by Locke (as cited in Elizabeth \& Adams, 2001) is that job satisfaction is "a pleasurable or positive emotional state resulting from the appraisal of one's job or job experiences". Cranny, Smith, and Stone (as cited in Brown \& Lent, 2004) defined job satisfaction as in "an affective reaction to a job that is preferred". Hulin and Judge (2003) said that job satisfaction is a psychological response to one's job that individual captures from his or her work experiences. According to Bradley \& Brain (2003), job satisfaction is a pleasurable emotional state of the employees that the individual derives from his or her job content and 
experiences. In summary, job satisfaction can be explained as one's perceived congruence or discrepancy among desire and its outcomes and the importance of what the employee expects from his or her job. Job satisfaction may occur when an individual feels that he or she has accomplished an important task, and it will be valued or recognized.

\section{Job Satisfaction in Nursing}

Nurses hold a majority of positions in the most health care organizations and are considered to be vital for ensuring the quality of patient care and cost minimization (O'Brien-Pallas, Thomson, Alksnis, \& Bruce, 2001). Many studies about job satisfaction confirmed that quality of health-care and nurses' job satisfaction are interrelated (Mrayyan, 2006; Adams \& Bond, 2000). Therefore, job satisfaction among nurses should be a great concern for any health care organizations. Molinari and Monserud (2008) defined that nurses' job satisfaction as the extent to which the difference between the amount of rewards received by nurses and the amount they believed that they should receive. Stamps (as cited in Taunton et al., 2004) viewed nurses' job satisfaction as a complex construct that captures individual nurses' reactions to the specific components of their job.

Nurses' job satisfaction and their commitments have always been important issues for health care administrators. In addition, nurses' job satisfaction studies on health care organization discovered that nurses' job satisfaction and dissatisfaction has correlation with turnover and retention of employees, quality care, and intent to leave (Buchan \&Calman, 2005; Larrabee, Jenny, \&Ostrow, 2003; Mrayyan, 2006). Moreover, some studies identified the association between nurses' job satisfaction and patient satisfaction (Allen, 2005; Kangas et al., 1999). Thus, it can be concluded that nurses' job satisfaction has a greater outcome for health care organization and its failure or success, particularly regarding the quality of care, patient satisfaction, which in turn increases the nurses' job performance, job retention, and reduces turnover and absenteeism.

\section{Definition of Organizational Environment}

Organizational environment, manifested in a variety of human resource practices, is an important predictor of organizational success. An early definition given by Forehand and Gilmer suggested that the organizational environment is a set of descriptive characteristic of an organization that is relatively enduring over a period. These characteristics differentiate one organization from other and influence the human behavior (Smith, 1994). According to Litwin and Stringer (1968), the organizational environment is a set of measurable properties of the work environment, perceived directly or indirectly by the people who live and work in this environment and assumed to influence their motivations and behaviors. Tagiuri and Litwin (as cited in Mullins,
2002) defined the organizational environment as a relatively stable state of the internal environment that is practiced by its member, influence workers behaviors and can be explained with the values of the organization. George et al.(as cited in French, 1994) gave a directional definition of organizational environment as the measurable and collective insight of organization's members about different aspects of working life that can affect employee's level of motivations and behaviors, like: the organization's culture, the practiced leadership styles, the nature of structure, and employment policies and practices.

Hong \&Kaur (2008) defined the organizational environment as a global feeling of one's organization and personal impact of the workplace environment that influences the individual's work behaviors and jobrelated attitudes.

\section{OBJective OF The Study}

This study consists of the following objectives:-

- To determine the relationship between organizational environments and nurse's job satisfaction.

- To identify influencing factors of both organizational environments and nurse's job satisfaction.

\section{CONCEPTUAL FRAMEWORK}

Two conceptual domains, nurses' job satisfaction and organizational environment were used in this framework. For nurses' job satisfaction, a synthesis of Stamp's work (1997) and related literature was conducted and resulted in conceptualizing six components of nurses' job satisfaction. These are autonomy, payment, task requirements, organization policies, interaction, and professional status (Stamps, 1997).

The second domain was the organizational environment. Stringer's six dimensions of the organizational environment (2002) were used to conceptualize nurses' perception regarding the organizational environment. These are structure, standards, responsibility, reward and recognition, support and commitment (Stringer, 2002) (Figure 1).

\begin{tabular}{|l|l|}
\hline Organizational environment & $\begin{array}{l}\text { Nurses' Job Satisfaction } \\
\text { 1. Structure }\end{array}$ \\
2. Standards & $\begin{array}{l}\text { 1. Autonomy } \\
\text { 2. Payment } \\
\text { 3. Responsibility }\end{array}$ \\
$\begin{array}{l}\text { 4. Reward and Recognition } \\
\text { 5. Support }\end{array}$ & $\begin{array}{l}\text { 4. Organizational policies } \\
\text { 6. Commitment } \\
\text { (Stringer, 2002) }\end{array}$ \\
& $\begin{array}{l}\text { 5. Interactions } \\
\text { 6. Professional Status } \\
\text { (Stamps, 1997) }\end{array}$ \\
\hline
\end{tabular}

Figure 1: Conceptual Relationship between Organizational environment and Nurses' Job Satisfaction

\section{RESEARCH Hypothesis}

To study the relationship between Nurse Job Satisfaction and different types of organizational factors, the following hypotheses were formulated. 


\section{Hypothesis}

$\mathrm{H}_{1}$ : There is no positive relationship between Nurse Job Satisfaction and structure of an organization.

$\mathrm{H}_{2}$ : There is no positive relationship between Nurse Job satisfaction and organization responsibility.

$\mathrm{H}_{3}$ : There is no positive relationship between Nurse Job satisfaction and reward and recognition

$\mathrm{H}_{4}$ : There is no positive relationship between Nurse Job satisfaction and standard of organization.

$\mathrm{H}_{5}$ : There is no positive relationship between organizational environment and payment of Nurse.

$\mathrm{H}_{6}$ : There is no positive relationship between organizational environment and interaction of Nurse.

$\mathrm{H}_{7}$ : There is no positive relationship between organizational environment and task requirement of Nurse.

$\mathrm{H}_{8}$ : There is no positive relationship between organizational environment and organizational policy.

\section{Methodology}

To investigate the factors that have influence on job satisfaction of nurse within the health care context in Bangladesh, the following research methodology was adopted. The study was conducted at three private medical colleges and hospital in Bangladesh. One hundred and thirty-nine (139) of the respondents were collected by applying a convenient sampling method at the different hospitals with minimum working experiences and involved with direct patient care in Dhaka city. Data were collected by using the face to face interview / self-administered questionnaire during June to August2014. Based on literature review, the questionnaire was divided into three parts: the first part included general information about the nurse (gender, age, level of education, experience, etc.) and the second part was designed to assess organizational environment perceptions (structure, responsibility, reward and recognition, standards, support, and commitment) and third part was designed to assess nurse job satisfaction perceptions about interaction, payment, task requirement, organizational policy, autonomy, and professional status that have an effect on nurse job satisfaction, using a fivepoint Likert scale ranging from 1" strongly disagree" to 5 "strongly agree". Microsoft Excel, SPSS, and AMOS-21 software were used for analyzing data. Cronbach's alpha, the reliability coefficient 0.75 was obtained from the overall measures in this study.

\section{ANALYSIS AND FINDING OF RELATIONSHIP BETWEEN ORGANIZATIONAL ENVIRONMENT AND NURSE JOB SATISFACTION IN BANGLADESH}

Table 1 shows that about 100\% of the respondents are female. The age distribution of the respondents shown in the table indicates that 40 respondents $(28.77 \%), 39$ $(28.06 \%), 10(7.19 \%)$ out of 139 are aged between (20-25), (25-30), and (30 and above) years respectively whose experience 0-5 years. Again, the respondents 9 (6.47\%), 21 $(15.1 \%), 10$ (7.19\%) out of 139 are aged (20-25), (25-30), and (30 and above) years respectively whose experience 6-10 years. On the other hand, the respondents $0(0 \%), 2$ $(1.4 \%), 8(5.76 \%)$ out of 139 are aged (20-25), (25-30), and (30 and above) years respectively whose experience ten years and above.

Table 1: Frequency, Percentages, Mean and Standard Deviation of Demographic Characteristics of the different type of respondents which is discuss below. $(\mathrm{N}=139)$

\begin{tabular}{|c|c|c|}
\hline & Frequency & Percentage \\
\hline \multirow{3}{*}{$\begin{array}{l}\text { Age (years) } \\
\text { Mean=28, S.D=4.25, Min.- } \\
\operatorname{Max}=20-45\end{array}$} & $20-25$ & 49 \\
\hline & $25-30$ & 62 \\
\hline & $30+$ & 28 \\
\hline \multirow[t]{2}{*}{ Gender } & Male & 0 \\
\hline & Female & 139 \\
\hline \multirow[t]{2}{*}{ Religion } & Muslim & 121 \\
\hline & Non-Muslim & 18 \\
\hline \multirow[t]{3}{*}{ Marital Status } & Single & 26 \\
\hline & Married & 109 \\
\hline & Divorced & 4 \\
\hline \multirow[t]{3}{*}{ Level Education in Nurse } & SSC & 38 \\
\hline & HSC & 41 \\
\hline & Diploma in Nurse & 60 \\
\hline \multirow{3}{*}{$\begin{array}{l}\text { Year of Working } \\
\text { Experience in Nurse }\end{array}$} & \begin{tabular}{|l|}
$0-5$ years \\
\end{tabular} & 89 \\
\hline & 6-10 years & 40 \\
\hline & Above 10 years & 10 \\
\hline \multirow[t]{2}{*}{ Current Position } & Nurse in Charge & 30 \\
\hline & Staff Nurse & 109 \\
\hline
\end{tabular}

Table 2 shows that majority of the respondents that is 62 (44.6\%) whose age between 25-30 years, a maximum number of respondents that is $124(89.2 \%)$ who are female. This study is female dominated and all the respondents are Muslim. In marital status, the majority number of the respondent that is $109(78.7 \%)$ who are married, also the level of education in nurse $43.2 \%$ respondents have Diploma in Nurse Degree. In the year of working experience in nurse, the majority number of the respondent that is $89(64 \%)$ whose experience $0-5$ years. In the current position in nurse, the maximum number of the respondent that is 109 (78.4\%) who are the staff nurse.

Table 2: Cross tabulation of age of respondents and years of experience of different type of respondent

\begin{tabular}{|c|c|c|c|c|}
\hline $\begin{array}{c}\text { Age of } \\
\text { respondents }\end{array}$ & \multicolumn{3}{|c|}{ Year Of Experience } & \multirow{2}{*}{ (0-5 years } \\
\cline { 2 - 4 } 6-10 years & Above 10 years & Total \\
\hline $20-25$ years & $\begin{array}{c}40 \\
(28.77 \%)\end{array}$ & $\begin{array}{c}9 \\
(6.47 \%)\end{array}$ & $\begin{array}{c}0 \\
(0 \%)\end{array}$ & $\begin{array}{c}49 \\
(35.26 \%)\end{array}$ \\
\hline $25-30$ years & $\begin{array}{c}39 \\
(28.06 \%)\end{array}$ & $\begin{array}{c}21 \\
(15.10 \%)\end{array}$ & $\begin{array}{c}2 \\
(1.4 \%)\end{array}$ & $\begin{array}{c}62 \\
(44.60 \%)\end{array}$ \\
\hline $\begin{array}{c}30 \text { years } \\
\text { and above }\end{array}$ & $\begin{array}{c}10 \\
(7.19 \%)\end{array}$ & $\begin{array}{c}10 \\
(7.19 \%)\end{array}$ & $\begin{array}{c}8 \\
(5.76 \%)\end{array}$ & $\begin{array}{c}28 \\
(20.14 \%)\end{array}$ \\
\hline Total & $\begin{array}{c}89 \\
(64.03 \%)\end{array}$ & $\begin{array}{c}40 \\
(28.78 \%)\end{array}$ & $\begin{array}{c}10 \\
(7.19 \%)\end{array}$ & 139 \\
\hline
\end{tabular}




\section{FACTOR ANALYSIS OF ORGANIZATIONAL ENVIRONMENT}

Exploratory factor analysis is a widely utilized and broadly applied statistical technique in social science. A total of 139 usable survey responses were analyzed in this section. The Eigen values, the percentage of total variance and the rotated sum of squared loadings have been shown below. The factor matrix as obtained in the principal component analysis has also been further subjected to Varimax Rotation. An examination of Eigen values has led to retention of 4 factors. These factors are accounted for $23.03 \%, 18.82 \%, 10.90 \%$, and $8.64 \%$ of the variation. This implies that $61.4 \%$ variance is explained by the four factors and the remaining variance is explained by other factors. The four factors found from rotated factor matrix, have been discussed in the following factors paragraph.

\begin{tabular}{|c|c|c|c|c|}
\hline \multirow[t]{2}{*}{ Component Matrix } & \multicolumn{4}{|c|}{ Factor Loading } \\
\hline & $\mathrm{F}_{1}$ & $\mathrm{~F}_{2}$ & $F_{3}$ & $\mathrm{~F}_{4}$ \\
\hline \multicolumn{5}{|l|}{ Factor-1 (Organizational Structure) } \\
\hline $\begin{array}{l}\text { Organizational vision, mission, values, } \\
\text { goals, and objectives are clearly } \\
\text { defined that influence me for better } \\
\text { performance. }\end{array}$ & .853 & & & \\
\hline $\begin{array}{l}\text { In this organization, it is sometimes } \\
\text { unclear who has assigned position to } \\
\text { make decision. }\end{array}$ & .567 & & & \\
\hline \multicolumn{5}{|l|}{$\begin{array}{ll}\text { Factor-2 } & \text { (Organizational } \\
\text { Responsibility) } & \end{array}$} \\
\hline $\begin{array}{l}\text { We do not rely too heavily on } \\
\text { individual judgment in this } \\
\text { organization; the most judgment is } \\
\text { depended on group or committee. }\end{array}$ & & .842 & & \\
\hline $\begin{array}{l}\text { One of the problem in this } \\
\text { organization is that individual won't } \\
\text { take responsibility. }\end{array}$ & & .735 & & \\
\hline $\begin{array}{l}\text { Management makes an effort to talk } \\
\text { with you about Career opportunities. }\end{array}$ & & .785 & & \\
\hline \multicolumn{5}{|l|}{ Factor-3 (Reward and Recognition) } \\
\hline $\begin{array}{l}\text { We have a promotion system here that } \\
\text { helps the best man / woman to rise to } \\
\text { the top }\end{array}$ & & & .768 & \\
\hline $\begin{array}{l}\text { There is not enough reward and } \\
\text { recognition given in this organization } \\
\text { for doing good work. }\end{array}$ & & & .646 & \\
\hline \multicolumn{5}{|l|}{ Factor-4 (Organizational Standard) } \\
\hline $\begin{array}{l}\text { In this organization, we set a very high } \\
\text { standard for performance. }\end{array}$ & & & & .894 \\
\hline $\begin{array}{l}\text { The management style of the } \\
\text { organization relies on more on } \\
\text { development of staff than on rules. }\end{array}$ & & & & .722 \\
\hline $\begin{array}{l}\text { I would accept almost any types of Job } \\
\text { assignment to continue working in the } \\
\text { organization. }\end{array}$ & & & & .532 \\
\hline Eigen Value & 2.764 & 2.259 & 1.31 & 11.038 \\
\hline$\%$ of Variance & 23.03 & 18.82 & 10.9 & 8.649 \\
\hline Cumulative $\%$ & 23.03 & 41.85 & 52.8 & \begin{tabular}{|l|l|}
3 & 61.4 \\
\end{tabular} \\
\hline \multicolumn{5}{|c|}{$\begin{array}{l}\text { Extraction method: Principal Component } \\
\text { Analysis Rotation method: Varimax with } \\
\text { Kaiser Normalization }\end{array}$} \\
\hline
\end{tabular}

Factor-1 (Organizational Structure) explains 23.03\% of the total variations existing in the variable set. This includes variable $X_{1}$, and $X_{2}$. On the basis of factor loadings on those variables a major cluster was formed. These factors belong to influence by the organizational characteristics, and unclear decision maker. So, it provides a basis for the conceptualization of a dimension which may be identified as organizational structure factor.

Factor-2 (Organizational responsibility) explains 18.82\% of the total variations existing in the variable set. This includes variable $X_{3}, X_{4}$, and $X 5$.On the basis of factor loadings on those variables a major cluster was formed. These factors belong to lacking of responsibilities, individual judgment, and career opportunity. So, it provides a basis for the conceptualization of a dimension which may be identified as organizational responsibility factor.

Factor-3 (Reward \& Recognition) explains $10.90 \%$ of the total variations existing in the variable set. This includes variable $X_{6}, X_{7}$. On the basis of actor loadings on those variables a major cluster was formed. This factor belongs to the better promotional system, and inadequate of reward \& recognition. So, it provides a basis for the conceptualization of a dimension which may be identified as reward and recognition factor.

Factor-4 (Organizational Standard) explains $8.64 \%$ of the total variations existing in the variable set. This includes variable $\mathrm{X}_{8}, \mathrm{X}_{9}$, and $\mathrm{X}_{10}$. On the basis of factor loadings on those variables a major cluster was formed. This factor belongs to ensure very high standard performance, management style, and job assignment to continue working. So, it provides a basis for the conceptualization of a dimension which may be identified as organizational standard factor.

\section{FACTOR ANALYSIS OF NURSE JOB SATISFACTION}

Exploratory factor analysis is a widely utilized and broadly applied statistical technique in social science. A total of 139 usable survey responses were analyzed in this section. The Eigen values, the percentage of total variance and the rotated sum of squared loadings have been shown below. The factor matrix as obtained in the principal component analysis has also been further subjected to Varimax Rotation. An examination of Eigen values has led to retention of 4 factors. These factors are accounted for $25.11 \%, 18.6 \%, 12.3 \%$, and $9.24 \%$ of the variation. This implies that $65.3 \%$ variance is explained by the four factors and the remaining variance is explained by other factors. The four factors found from rotated factor matrix, have been discussed in the following paragraph.

Factor-1 (Payment of Nurse) explains 25.11\% of the total variations existing in the variable set. This includes variable $\mathrm{X}_{11}, \mathrm{X}_{12} \mathrm{On}$ the basis of factor loadings on those variables a major cluster was formed. This factor belongs to payment according to skill and qualification, benefit from extra work. So, it provides a basis for the conceptualization of a dimension which may be identified as payment of nurse factor. 


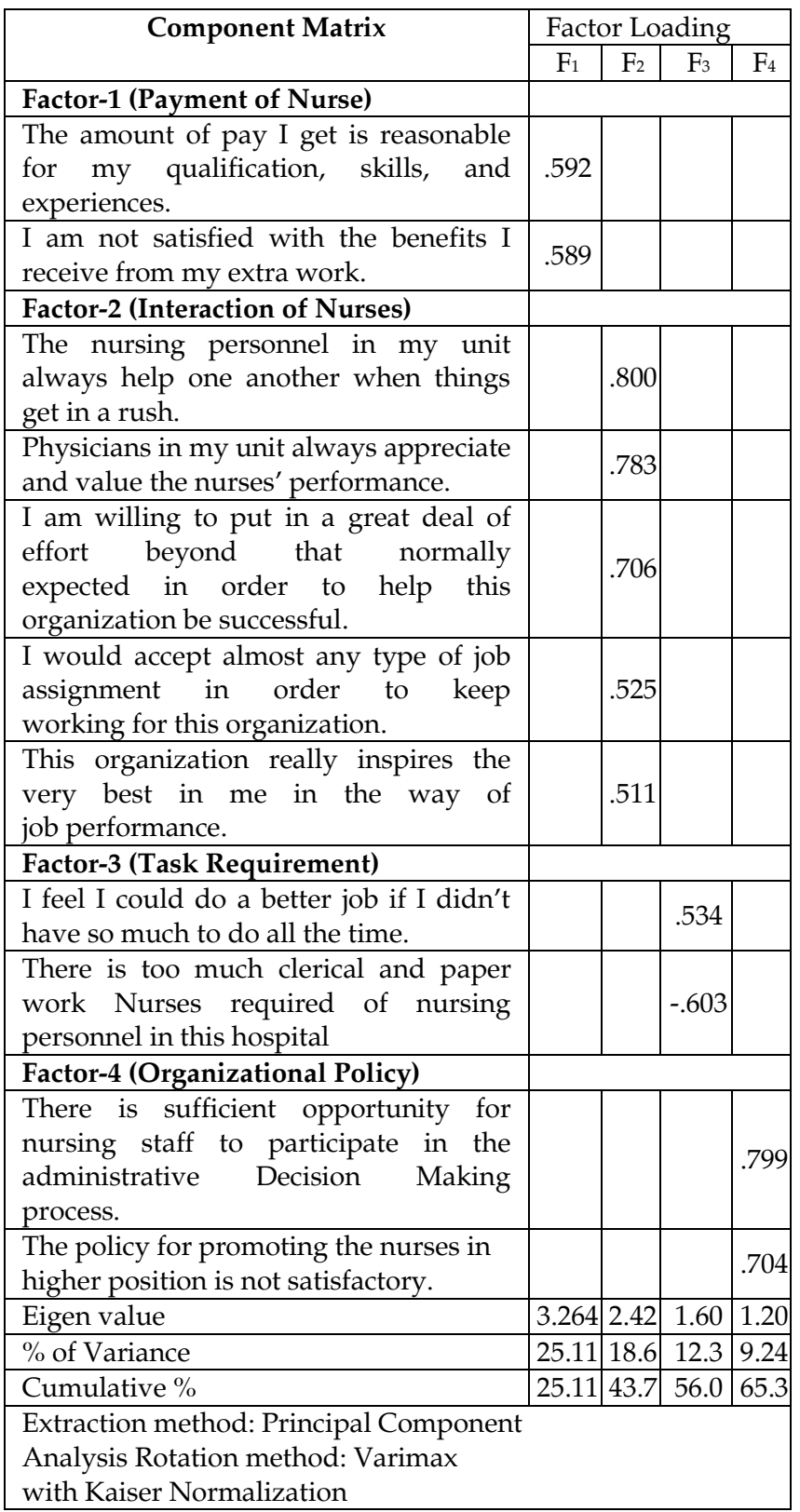

1=Strongly Disagree, 5= Strongly Agree. Kaiser-MeyerOlkin measure of sampling adequacy $=0.645$. Bartlett's test of sphericity $\mathrm{p}<0.000$.

Factor-2 (Interaction of Nurse) explains $18.6 \%$ of the total variations existing in the variable set. This includes variable $X_{13}, X_{14}, X_{15}, X_{16}$ and $X_{17}$.On the basis of factor loadings on those variables a major cluster was formed. This factor belongs to appreciate by the physician, helped by the nursing personnel, helped by the organization, willingly accept any job assignment, and inspires must be essential for job performance. So, it provides a basis for the conceptualization of a dimension which may be identified as interaction of nurse factor.

Factor-3 (Task Requirement) explains $12.3 \%$ of the total variations existing in the variable set. This includes variable $\mathrm{X}_{18}$, and $\mathrm{X}_{19}$. On the basis of factor loadings on those variables a major cluster was formed. This factor belongs to "Better performance under relaxed schedule", "Unnecessary clerical and paper work for Nurses". So, it provides a basis for the conceptualization of a dimension which may be identified as task requirement factor.

Factor-4 (Organizational Policy) explains 9.24\% of the total variations existing in the variable set. This includes variable $\mathrm{X}_{20}$, and $\mathrm{X}_{21}$. On the basis of factor loadings on those variables a major cluster was formed. This factor belongs to Opportunity to participate in the administrative decision making process, and inadequate policy to promote nurses in higher positions. So, it provides a basis for the conceptualization of a dimension which may be identified as organizational policy factor.

\section{CONFIRMATORY FACTOR ANALYSIS (CFA)}

To confirm the factor structure, CFA was performed. From the default model, the CFA results obtained using AMOS are presented in the Table 10.1. The fit indices demonstrated a good fit of the measurement models to the data. The entire model was tested based on the measurement model previously validated from CFA in this study (Fig. 2). The fit indices of the entire model in both organizational environment and nurse job satisfaction were $\chi^{2} / \mathrm{df}=3.1939$ $(\chi 2=124.5623, \mathrm{df}=39)$, and $\chi^{2} / \mathrm{df}=3.143(\chi 2=122.5633, \mathrm{df}=39)$; GFI=0.9181, and 0.8711; AGFI=0.8157, and 0.7825; $\mathrm{NFI}=0.839$, and $0.7448 ; \mathrm{CFI}=0.8844$, and 0.8035 respectively (Table 5). Although a relative Chi-square statistic in both organizational environment and nurse job satisfaction were $\chi^{2} / \mathrm{df}=3.1939$, and $\chi^{2} / \mathrm{df}=3.143$ indicated a good fit, other indices were at the lower end of acceptable ranges to indicate a good model fit. From Organizational Environment, we also compared the magnitude of total effects between Organizational Structure, Organizational Responsibility, and Organizational Standard respectively. The total effect of Organizational Structure and Overall Nurse Job Satisfaction was 0.14 . This was the effect of organizational structure on overall nurse job satisfaction (ONJS); when organizational structure changed 1 unit, overall nurse job satisfaction (ONJS) change by 0.14 units. Again, the total effect of organizational responsibility and overall nurse job satisfaction (ONJS) was 0.67.This was effect of organizational responsibility on overall nurse job satisfaction (ONJS); when organizational responsibility changed 1 unit, overall nurse job satisfaction (ONJS) change by 0.67 units. The total effect of organizational standard and overall nurse job satisfaction (ONJS) was 0.40.This was the effect of the organizational standard on overall nurse job satisfaction (ONJS); when organizational standard changed 1 unit, overall nurse job satisfaction (ONJS) changed by 0.40 units. Therefore, we can conclude that the effect of organizational responsibility and organizational standard were more dominant than the effects in explaining the total effect. From Nurse Job Satisfaction, we also associated the magnitude of total effects between payment of nurse, the interaction of nurse, and organizational policy respectively. The total effect of the payment of nurse and the overall organizational environment was 0.14 . This was the effect of the payment of 
nurse on the overall organizational environment (OGE); when payment of nurse changed 1 unit, overall organizational environment (OGE) change by 0.14 . The total effect of interaction and the overall organizational environment was 0.57 . This was the effect of the interaction of nurse on the overall organizational environment (OGE); when the interaction of nurse $(\mathrm{ON})$ changed 1 unit, the overall organizational environment (OGE) changed by 0.57 . Again, the total effect of organizational policy and overall organizational environment was 0.84 . This was the effect of organizational policy on the overall organizational environment (OGE); when the organizational policy changed 1 unit, overall organizational environment (OGE) changed by 0.84 unit. Therefore, we can conclude that the two effects (interaction of nurses, and organizational policy) were more dominant than the effects in explaining the total effect.

Figure 2(a,b): Path diagram of Organizational Environment and Nurse Job Satisfaction are shown below

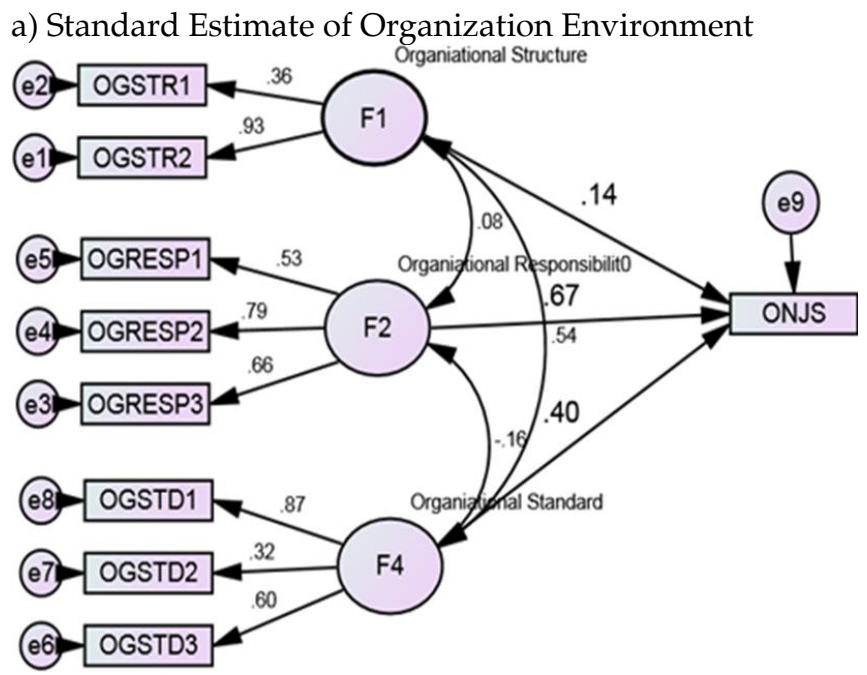

b) Standard Estimate of Nurse Job Satisfaction

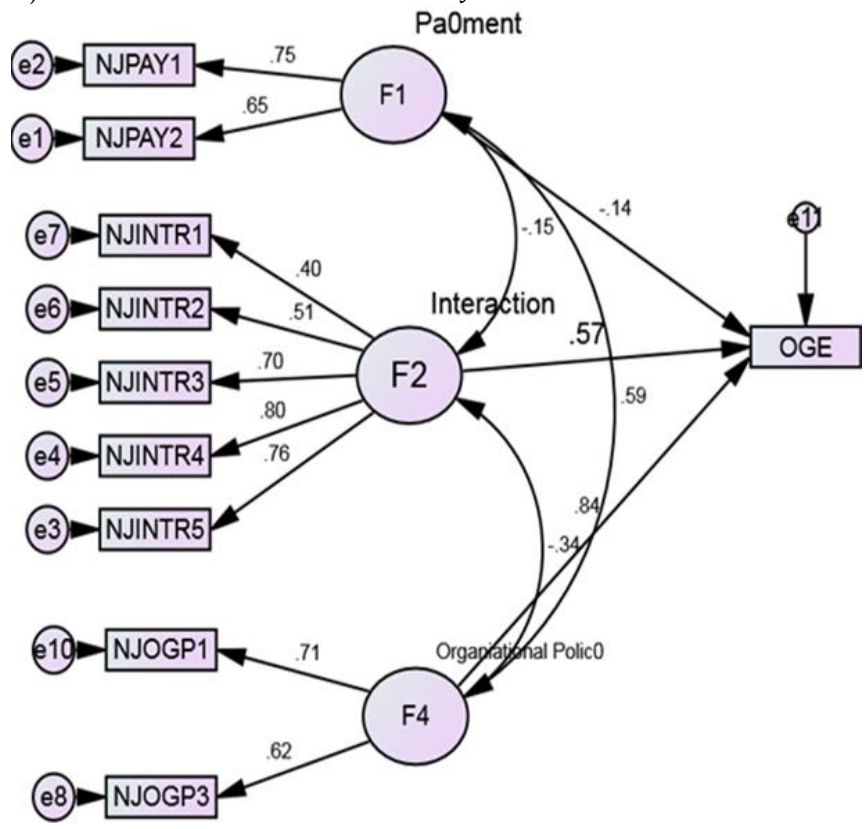

Table 3: Summary of goodness of fit indices for full testing

\begin{tabular}{|l|c|c|c|c|c|c|c|c|c|c|}
\hline & Model & RMR & GFI & AGFI & NFI & CFI & RMSEA & $\begin{array}{c}\text { Chi-square } \\
\text { value }\end{array}$ & d.f & $\begin{array}{c}\text { Relative } \\
\text { Chi-square } \\
\text { value }\end{array}$ \\
\hline $\begin{array}{l}\text { Organizational } \\
\text { Environment }\end{array}$ & $\begin{array}{c}\text { Default } \\
\text { model }\end{array}$ & .1065 & .9181 & .8157 & .839 & .884 & .1144 & 124.5623 & 39 & $3.1939^{* * *}$ \\
\hline $\begin{array}{l}\text { Nurse Job } \\
\text { Satisfaction }\end{array}$ & $\begin{array}{l}\text { Default } \\
\text { model }\end{array}$ & .1211 & .8715 & .7825 & .744 & .803 & .1246 & 122.5633 & 39 & $3.143^{* * *}$ \\
* Significant at 5\% probability level, *** Significant at 1\% \\
probability level.
\end{tabular}

\section{CONCLUSION}

This descriptive correlation study was designed to describe and examine the relationship between organizational environment and nurse job satisfaction within the health care context in Bangladesh. A brief summary of the study findings, strengths, limitations, implications, and recommendations are described as follows: By using factor analysis, only four influential factors like organizational structure, organizational responsibility, reward \& recognition, organizational standard have been influenced for nurse job satisfaction. On the other hand, organizational environment has been influenced by four influential factors of nurse job satisfaction like as "payment of nurse, the interaction of nurse, task requirement, and the organizational policy. By using confirmatory factor analysis, only three influential factors like organizational structure, organizational responsibility, and organizational standard have been found influential for nurse job satisfaction. On the other hand, the organizational environment has been influenced by three influential factors of nurse job satisfaction like as "payment of nurse, the interaction of nurse, and organizational policy.

\section{RECOMMENDATIONS}

\section{Recommendations for Organization}

- The organizational environment must be well decorated.

- Inspiration must be increased among nurses.

- Anyhow nurses must be inspired by the organization that the reason Nurse must be committed to giving better services.

- Management should take better management policies that can consist better environment for nurses.

- Organizational structure should be better than that of other organizations.

\section{Recommendations for Nurses}

- $\quad$ The Nurse must be motivated to perform better and maintain their task report appropriately.

- The Nurse should be allowed to make some decision.

- Nurses' job should be properly evaluated, and promotion should be given based on performance.

- Nurses should be obedient for organizational policy and structure that can give a better environment for nurses. 


\section{REFERENCES}

Adams, A., \& Bond, S. (2000). Hospital nurses' job satisfaction, individual and organizational characteristics. Journal of Advanced Nursing, 32 (536-543).

Allen, D. E. (2005). Patient care delivery model improves nurses' job satisfaction. The Journal of Continuing Education in Nursing, 36 (277-282).

Bradley, E. W., \& Brian, S. D. (2003). Job satisfaction in the public sector: The role of the work environment. The American Review of Public Administration, 33 (70-90).

Bradley, J. R., \& Cartwright, S. (2004). Social support, job stress, health, and job satisfaction among nurses in the United Kingdom. International Journal of Stress Management. 10 (163-182).

Brown, S. D., \& Lent, R. W. (Eds.). (2004). Career development and counseling: Putting theory and research in work. New York, Wily: John Wiley \& Sons, Inc.

Buchan, J., \& Aiken, L. (2008). Solving nursing shortages: A common priority. Journal of Clinical Nursing, 17 (3262-3268).

Buchan, J., \& Calman, L. (2005). The global shortage of registered nurses: An overview of issues and actions. Geneva, Switzerland: International Council of Nurses.

Buss, J. (1988). Job satisfaction, powerlessness and locus of control. Western Journal of Nursing Research, 10 (718-731).

Elizabeth, J. T., \& Adams, A. E. (2001). The changing nature of nurses' job satisfaction: An exploration of sources of satisfaction in the 1990s. Journal of Advanced Nursing, 30 (150-158).

French, W. L. (1994). Human resource management (3rd ed.). Boston, NJ: Houghton Mifflin Company.

George, D., \& Mallery, P. (2003). "SPSS for windows step by step: A simple guide and reference." 11.0 update ( $4^{\text {th }}$ ed.). Boston: Allyn\& Bacon

Gliem, J.A., and R.R. Gliem, (2003). “Calculating, Interpreting and Reporting Cronbach's Alpha Reliability Coefficient for Likert-Type Scales. 2003" Midwest Research to Practice Conference in Adult, Continuing, and Community Education.

Hair, I. F., Anderson, R. E., Tatham, R. L., \& Black, W. C. (1998). Multivariate data analysis ( $5^{\text {th }}$ ed.), Upper Saddle River, NJ: Prentice Hall.

Henry, J., \& Henry, L. (2004). Caring from the inside out strategies to enhance nurse retention and patient satisfaction. Nurse Leader 2 (28-32).

Hong, L. C., \&Kaur, S. (2008). A relationship between organizational climates, employee personality and intention to leave. International Review of Business Research Papers, 4 (1-10).

Hossain, D. (2008). Nurses' satisfaction on job performance provided in public $\mathcal{E}$ private hospitals. Unpublished master's thesis, Northern University, Dhaka, Bangladesh.

Hulin, C. L. \& Judge, T. A. (2003). Job attitudes. In W. C. Borman, D. R. Ilgen, \& R. J. Klimoski (Eds). Handbook of psychology: Industrial and organizational psychology, 12.New York: San Francisco.

Kaiser, H. F. (1974). An index of factorial simplicity. Psychometrika. 39 (31-36).

Kangas, S., Kee, C., \& McKee-Waddle, R. (1999). Organizational factors, nurses' job satisfaction, and patient satisfaction with nursing care. Journal of Nursing Administration, 29 (32-42).

Larrabee, J. H., Jenny, M. A., \& Ostrow, C. L. (2003). Predicting registered nurse job satisfaction and intent to leave. Journal of Nursing Administration, 33, (271-283).
Likert, R. (1931). "A technique for the measurement of attitudes. "Archives of Psychology. New York: Columbia University Press.

Litwin, G. H., \& Stringer, R. A. (1968). Motivation and organizational climate Boston, MA: Division of Research, Harvard University.

Locke, E. A. (1968). Toward a theory of task motivation and incentives. Organizational Behavior \& Human Performance, 3 (157-189). (Abstract).

Mok, E., \& Au-Yeung, B. (2002). The relationship between the organizational climates and empowerment of nurses in Hong Kong. Journal of Nursing Management, 10 (129-137).

Mrayyan, M. T. (2006). Jordanian nurses' job satisfaction, patients' satisfaction and quality of nursing care. International Nursing Review, 53 (224-230).

Mullins, L. J. (2002). Management and organizational behavior (6th ed.).London: Pearson Education.

Nunnally, J. (1978). Psychometric Theory, McGraw-Hill Book Co., New York, NY.

Nursing Taskforce (1994). National plan of action for nursing development in Bangladesh. Directorate of Nursing Services, Ministry of Health and Family Welfare, Bangladesh.

O'Brien-Pallas, L., D. Thomson, Alksnis, C., \& Bruce, S. (2001). The economic impact of nurse staffing decisions: Time to turn down another road? Healthcare Quarterly, 4 (42-50).

Robbins, S. P. (1996). Organizational behavior: Concepts, controversies, applications (7th ed.). Englewood Cliffs, NJ: Prentice Hall.

Smith, M. (1994). The relationship between organizational climate and employee perceptions of personnel management practices. Public Personnel Management, 23 (453-68).

Spector, P. E. (1997). Job satisfaction: Application, assessment, causes, and consequences. Thousand Oaks, CA: Sage.

Stamps, P. L. (1997). Nurses' and work satisfaction: An index of Measurement ( $2^{\text {nd }}$ ed.). Chicago: Health Administration Press.

Stringer, R. (2002). Leadership and organizational climate. Upper Saddle River, NJ: Prentice Hall.

Tabachnick, B. G., \& Fidell, L. s. (2001), Using multivariate statistics ( $4^{\text {th }}$ ed.)Boston, MA: Allyn and Bacon.

Taunton, R. L. Bott, M. J., Koehn, M. L. Miller, P., Rindner, E. Pace, K., et al. (2004). The NDNQI-Adapted Index of Work Satisfaction. Journal of Nursing Measurement, 12 (101-122).

World Health Organization. (2003). Nursing and midwifery workforce management: Guidelines. Regional Office for SouthEast Asia. New Delhi. ISBN, 9290222603.

Zaman, S. (2004). Poverty and violence, frustration and inventiveness: Hospital wards life in Bangladesh. Social Science E Medicine, 59 (2025-2036).

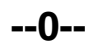

\section{SOCIAL SCIENCE RESEARCH NETWORK 2171 Monroe Avenue, Suite 203, Rochester, NY 14618, USA http://www.ssrn.com/en/ \\ AJTP Link: $\underline{\text { http://www.ssrn.com/link/American-Journal-Trade-Policy.html }}$}

